\title{
Xanthomonas oryzae PV. Oryzae IN EGYPT: IDENTIFICATION, VIRULENCE OF ISOLATES AND CULTIVARS REACTION. \\ Tolba, ${ }^{1}$ I. H. M. and R. I. El-Sharkawy ${ }^{2}$ \\ 1- Plant Pathology Branch, Dept. Agric. Botany, Fac. Agric., Al Azhar Univ., Cairo, Egypt. \\ 2- Plant Pathology Branch, Dept. Agric. Botany, Fac. Agric., Al Azhar Univ., Assuit, Egypt.
}

\begin{abstract}
Nine isolates of Xanthomonas oryzae pv. oryzae were isolated from symptomatic rice leaf samples collected from different rice-producing areas at Damietta governorate in Egypt during 2009 growing season. The isolates were identified on the basis of morphological, physiological and biochemical tests. The identity of these isolates were confirmed by the Biolog system and pathogenicity test. Virulence of isolates and cultivars reactions were investigated under experimental conditions. The abilities of isolates to cause lesions with different lengths across the cultivars Giza 176 and Sakha 101 were interpreted as virulence. Although typical bacterial blight symptoms were visible for all isolates on the two cultivars, diversity in virulence was observed among isolates. Isolates that were consistently associated with high or low virulence were statistically differentiated. Eleven Egyptian rice cultivars were inoculated by two isolates of $X$. oryzae pv. oryzae to identify the resistance response to this pathogen. Among tested cultivars, no resistant cultivars were found. According to used scale, all cultivars ranged from moderately susceptible to susceptible.
\end{abstract}

Keywords: Xanthomonas oryzae pv. oryzae, cultivar reaction, xanthomonadin pigments, Biolog system.

\section{INTRODUCTION}

Bacterial leaf blight caused by Xanthomonas oryzae pv. oryzae, a major bacterial disease of rice (Oryza sativa L.), is found in most irrigated, rainfed and deep water temperate and tropical rice growing areas, including all Asian countries, West Africa, Australia, South America and the Caribbean (Mew et al. 1982, Mew 1987).

Bacterial leaf blight appears on leaves of young plants, after planting out, as pale-green to grey-green water-soaked streaks near the leaf tip and margins. These lesions coalesce and become yellowish-white with wavy edges. Eventually, the whole leaf may be affected, becomes whitish or grayish and then dies (Bradbury 1970a; 1970b). Leaf sheaths and culms of the more susceptible cultivars may be attacked (Feakin 1971). Systemic infection, known as kresek (Reddy, 1984), results in desiccation of leaves and death, particularly of young transplanted plants. In older plants, the leaves become yellow and then die. In later stages, the disease may be difficult to distinguish from bacterial leaf streak caused Xanthomonas oryzae pv. oryzicola (Ou 1972). 
Many different races (or pathotypes) of the bacterium exist, distinguished by their behaviour on differential cultivars (Mew 1987). New races appear readily and the bacterium is very variable in virulence.

Host resistance has been used to control the disease, but $X$. oryzae pv. oryzae strains show extensive pathogenic differeniation and many pathotypes have been identified in major rice-growing countries (Mew 1987, Mew et al. 1992 and Yun et al. 1984).

Bacterial blight has the potential to become a destructive bacterial disease of rice in Egypt and can cause huge losses mainly because information regarding the pathogen and its effective control measures is lacking. Resistance to Bacterial leaf blight is known to be widely different with rice cultivars. This is due to the fact that the presences of different pathogenic races subsequently break the resistance of rice cultivars. So evaluating rice cultivars for Bacterial leaf blight resistance is a routine practice to overcome yield losses.

The purpose of the present study was to identify Xanthomonas oryzae pv. oryzae isolates then determine the relative virulence of these isolates and evaluate the resistance response of different Egyptian rice cultivars towards this pathogen.

\section{MATERIALS AND METHODS}

\section{Isolation of Xanthomonas oryzae pv. oryzae}

Rice leaves affected with bacterial leaf blight were collected from rice field located in Damietta governorate, during 2009. Symptoms on diseased plants collected in the field were characterized by water-soaked lesions typically associated with the margins of fully developed leaves. On mature leaves, lesions measured $10-20 \mathrm{~mm}$ wide and varied in length from $40 \mathrm{~mm}$ up to $200 \mathrm{~mm}$ in rare cases. Affected tissue on mature plants were necrotic and white to light tan in color.

Diseased leaf samples were cut into small pieces, $1 \mathrm{~cm}$ in length including the marginal portion of fresh lesions. These were placed in $70 \%$ Ethyl alcohol for 15 seconds, dipped in 1\% sodium hypochlorite solution for 1 minute and rinsed in sterile distilled water thrice. Each sample was then homogenized with $10 \mathrm{ml}$ sterile distilled water. The resulting suspension was diluted with sterile distilled water and appropriate dilution was streaked on XOS medium ( $\mathrm{Di}$ et al. 1991). This medium consisted of $20 \mathrm{~g}$ of sucrose, $2 \mathrm{~g}$ of peptone, $5 \mathrm{~g}$ of monosodium glutamate, $0.2 \mathrm{~g}$ of $\mathrm{Ca}(\mathrm{NO},)_{2}, 2 \mathrm{~g}$ of $\mathrm{K}_{2} \mathrm{HPO}_{4}$, $1 \mathrm{mg}$ of $\mathrm{Fe}(\mathrm{EDTA})$, cycloheximide $(100 \mathrm{mg} / 1)$, cephalexin $(20 \mathrm{mg} / 1)$, kasugamycin $(20 \mathrm{mg} / 1)$, and methyl violet $2 \mathrm{~B}(0.3 \mathrm{Mg} / \mathrm{ml})$ and $17 \mathrm{~g}$ of agar per liter. The $\mathrm{pH}$ of the medium was 6.8-7.0. The plates were incubated at $25^{\circ} \mathrm{C}$ for 4 days. Single-colony isolation was made. The yellow bacterial colonies that subsequently developed were subcultured on peptone sucrose agar (PSA) medium and grown at $25^{\circ} \mathrm{C}$ for 2 days (Devadath, 1989). For longterm preservation, the bacterial cells suspended in $10 \%(\mathrm{w} / \mathrm{v})$ skim-milk containing $0.05 \%$ L-glutamic acid were stored at $0{ }^{\circ} \mathrm{C}$ until needed. 
Identification Xanthomonas oryzae pv. oryzae

Colonies suspected of being Xan/homonas were initially identified on XOS based on typical morphology and color. Mucoid growth was tested by streaking onto YDC medium (Di et al 1991). Gram staining was done as described (Schaad 1988). The strains were further examined for physiochemical and biochemical features. Growth at 25, 28, 36, and $41^{\circ} \mathrm{C}$ was evaluated after $96 \mathrm{hr}$ in shake cultures of nutrient broth (Jones et al. 1989). Oxidase test was performed as described by Kovacs (1956). Catalase activity, casein hydrolysis, starch hydrolysis, acetoin production, indole production, urease production, and nitrate reduction were determined as described by Dye (1962). Gelatin hydrolysis, aesculin hydrolysis, phenylalanine deaminase activity, reduction of potassium tellurite $\left(\mathrm{K}_{2} \mathrm{TeO}_{3}\right)$, acid formation from carbohydrates, growth on carbon sources, and oxidativefermentative tests were performed as described by Vera Cruz et al. (1984). Production of $\mathrm{H}_{2} \mathrm{~S}$ from L-cysteine was determined by the method of Dye (1968). Pectinase activity was tested by the procedures of Beraha (1968) and Hildebrand (1971). Tolerance to triphenyl tetrazolium chloride was measured at 0.02 as described by Lovrekovich and Klement (1965). Hypersensitivity of tobacco (Nicotiana tabacum ) was determined on 35-day-old plants of cultivar Xanthi by the method of Gitaitis et al. (1987).

Xanthomonadin pigment analysis

Xanthomonadin pigments were detected and identified with scanning spectrophotometry and thin-layer chromatography (Irey and Stall 1981). An strain of Pseudomonas paucimobilis, and strain of Xanthomonas fragariae were used for comparison. Bacterial pigments were methanol-extracted from log phase cells grown in YDC broth. Pigments were spectrophotometrically analyzed and subjected to thin-layer chromatography. The absorption spectrum of the pigment extracts was determined with a Beckman DU-64 recording spectrophotometer (Beckman Instruments, Palo Alto, CA).

\section{Biolog system identity confirmation}

The Biolog system (Microlog 1Release 3.50 Biolog Inc., Hayward, $\mathrm{CA}$ ), based on patterns of carbon source utilization, also was used to confirm identity of the bacteria.

\section{Pathogenicity testing}

The pathogenicity of isolates was tested on rice seedlings of cultivar Giza 176. The leaf-clipping method (Kauffman et al., 1973) was followed to introduce the bacteria into 21-day-old potted plants. A Sterilized surgical pair of scissors was dipped in bacterial suspension. Leaves of all the plants in a pot were grasped in one hand and the top of three leaves were clipped off simultaneously. Pots contained approximately 50 plants. Treatments were replicated three times. Inoculations were repeated twice. Inoculum was prepared by suspending cells from $72 \mathrm{hr}$ old NBYA cultures in sterile distilled water to obtain $10^{9} \mathrm{cfu} / \mathrm{ml}$. Seedlings reaction was evaluated after 7 and 14 days of incubation in the greenhouse. Reisolation was made from the advancing margins of lesions, and identity was confirmed by Biolog system test 


\section{Virulence of isolates}

Virulence of isolates was assessed on 50-day-old potted plants of the rice cultivars Giza 176 and Sakha 101. The double-needle inoculation technique (Barton-Willis et al; 1989) was followed to introduce bacteria into the three uppermost leaves of three plants in each pot. A double sewing machine needle dipped into inoculum (prepared as described above) was used to stab fully expanded rice leaves once between the margin and midrib, perpendicular to the veins, $10 \mathrm{~cm}$ from the leaf tip. Only the second-youngest leaf per plant was inoculated.Treatments were replicated three times and arranged on a greenhouse bench in a completely random design. The experiment was repeated once. Virulence was determined on the basis of the percent leaf area affected by individual strains 14 days after inoculation. Percent of disease incidence was calculated using the following formula (Gnanamanickam et al., 1999):

\section{Cultivars reaction}

$$
\% \text { Disease incidence }=\frac{\text { Lesion length }}{\text { Total leaf length }} \times 100
$$

Eleven different rice cultivars were tested to evaluate their susceptibility by Xanthomonas oryzae pv. oryzae under greenhouse conditions. These cultivars include Giza 175, Giza 176, Giza 177, Giza 178, Giza 181, Giza 182, Sakha 101, Sakha 102, Sakha 103, Sakha 104 and Sakha 105. Two local isolates of Xanthomonas oryzae pv. oryzae ( designated as Xoo 1 and Xoo 2) were used in this test. Seeds of all the above mentioned cultivars were provided by agronomy department, agriculture faculty, Al-Azhar university, Cairo, Egypt.

inoculum preparation, inoculation method and disease evaluation were the same as described in the isolates virulence.

The score chart given in Table (1) was used to evaluate the response of host plant (Anonymous, 1996).

Table 1. Scale for evaluation of rice bacterial blight severity.

\begin{tabular}{|l|l|l|}
\hline Infection \% & Score & Host response \\
\hline $0 \%$ & 0 & Highly resistant (HR) \\
\hline$>1-10 \%$ & 1 & Resistant (R) \\
\hline$>10-30 \%$ & 3 & Moderately resistant (MR) \\
\hline$>30-50 \%$ & 5 & Moderately susceptible (MS) \\
\hline$>50-75 \%$ & 7 & Susceptible (S) \\
\hline$>75-100 \%$ & 9 & Highly susceptible (HS) \\
\hline
\end{tabular}

\section{Statistical analyses.}

Lesion length data for Virulence data of $X$. oryzae pv. oryzae isolates produced on the two rice cultivar and cultivars reaction (each cultivar-isolate combination) were subjected to one-way analysis of variance (ANOVA). Means were separated by Fisher's least significance tests $(P<0.05)$. All statistical analyses were performed using the SAS statistical package (Ver. 6.10, SAS Institute, Cary, NC). 


\section{RESULTS}

\section{Isolation}

Symptomatic rice tissue consistently yielded xanthomonad type colonies. Typical colonies of xanthomonad type were recovered from almost samples. In all, a lot of isolates were recovered that resembled $X$. oryzae pv. oryzae by producing typical colonies on XOS medium. These colonies appeared after 3 to 4 days at $28^{\circ} \mathrm{C}$ as light yellow, mucoid, round, and smooth (Fig 1).

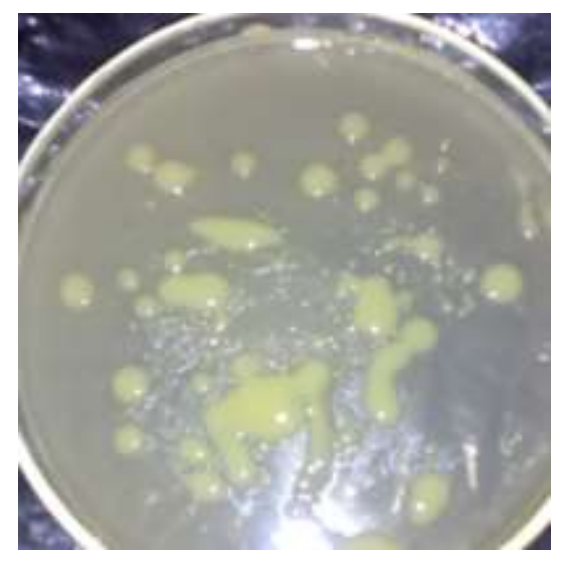

Fig. 1 Typical colonies of $X$. o. pv. oryzae on XOS medium

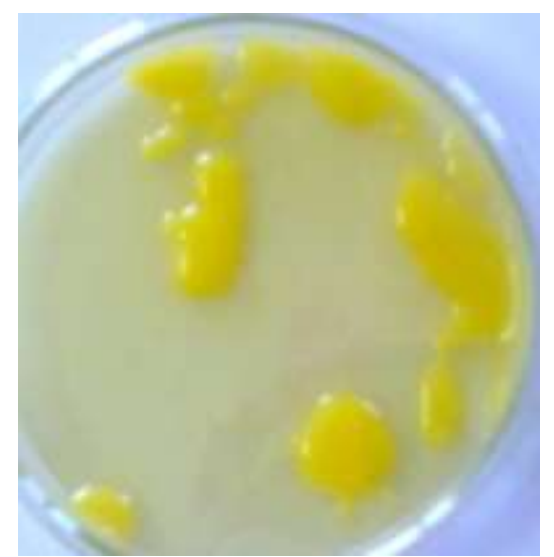

Fig. 2 Mucoid growth of $X$. o. pv. oryzae on YDC medium

\section{Identification}

The biochemical characteristics of all nine isolates were generally those associated with members of the genus Xanthomonas and were uniform for all isolates (Table 2). Cells were straight rods and Gram negative. Mucoid growth was present on YDC medium (Fig.2). 
Tolba, I. H. M. and R. I. El-Sharkawy

Table 2. Morphological and biochemical characteristics of nine bacterial isolates obtained from diseased rice leaf samples.

\begin{tabular}{|c|c|c|c|c|c|c|c|c|c|}
\hline \multirow[b]{2}{*}{ Test } & \multicolumn{8}{|c|}{ Isolate } & \multirow[b]{2}{*}{9} \\
\hline & 1 & 2 & 3 & 4 & 5 & 6 & 7 & 8 & \\
\hline Shape & Rod & Rod & Rod & Rod & Rod & Rod & Rod & Rod & Rod \\
\hline Colonies & Mucoid & Mucoid & Mucoid & Mucoid & Mucoid & Mucoid & Mucoid & Mucoid & Mucoid \\
\hline Gram staining & - & - & - & - & - & - & - & - & - \\
\hline \multirow{5}{*}{$\begin{array}{l}\text { Growth at: } \\
25 \mathrm{C} \\
28 \mathrm{C} \\
36 \mathrm{C} \\
41 \mathrm{C}\end{array}$} & & & & & & & & & \\
\hline & + & + & + & + & + & + & + & + & + \\
\hline & + & + & + & + & + & + & + & + & + \\
\hline & + & + & + & + & + & + & + & + & + \\
\hline & - & - & - & - & - & - & - & - & - \\
\hline Oxidase test & - & - & - & - & - & - & - & - & - \\
\hline $\begin{array}{l}\text { Oxidative } \\
\text { metabolism }\end{array}$ & + & + & + & + & + & + & + & + & + \\
\hline $\begin{array}{l}\text { Catalase } \\
\text { activity }\end{array}$ & + & + & + & + & + & + & + & + & + \\
\hline \multicolumn{10}{|l|}{ Hydrolysis of: } \\
\hline Aesculin & + & + & + & + & + & + & + & + & + \\
\hline Casein & + & + & + & + & + & + & + & + & + \\
\hline Gelatin & - & - & - & - & - & - & - & - & - \\
\hline Potato starch & + & + & + & + & + & + & + & + & + \\
\hline Rice starch & + & + & + & + & + & + & + & + & + \\
\hline \multicolumn{10}{|c|}{$\begin{array}{l}\text { Growth on sole } \\
\text { carbon source as }\end{array}$} \\
\hline Fructose & + & + & + & + & + & + & + & + & + \\
\hline Glycerol & - & - & - & - & - & - & - & - & - \\
\hline Trehalose & + & + & + & + & + & + & + & + & + \\
\hline D-xylose & + & + & + & + & + & + & + & + & + \\
\hline \multicolumn{10}{|l|}{ Acid from } \\
\hline L-arabinose & + & + & + & + & + & + & + & + & + \\
\hline Cellobiose & + & + & $\begin{array}{llll}+ & & l & l\end{array}$ & + & + & + & + & + & $\begin{array}{llll}+ & & l & l\end{array}$ \\
\hline D-fructose & + & + & + & + & + & + & + & + & + \\
\hline D-galactose & + & + & + & + & + & + & + & + & + \\
\hline D-mannose & + & + & + & + & + & + & + & + & + \\
\hline Glucose & + & + & + & + & + & + & + & + & + \\
\hline Sucrose & + & + & + & + & + & + & + & + & + \\
\hline Trehalose & + & + & + & + & + & + & + & + & + \\
\hline D-ribose & - & - & - & - & - & - & - & - & - \\
\hline L-rhamnose & - & - & - & - & - & - & - & - & - \\
\hline Salicin & - & - & - & - & - & - & - & - & - \\
\hline Sorbitol & - & - & - & - & - & - & - & - & - \\
\hline \begin{tabular}{|l|} 
Acetoin \\
production
\end{tabular} & - & - & - & - & - & - & - & - & - \\
\hline $\begin{array}{l}\text { Indole } \\
\text { production }\end{array}$ & - & - & - & - & - & - & - & - & - \\
\hline $\begin{array}{l}\text { Urease } \\
\text { production }\end{array}$ & - & - & - & - & - & - & - & - & - \\
\hline \begin{tabular}{|l}
$\mathrm{K}_{2} \mathrm{Te} 03$ \\
reduction
\end{tabular} & - & - & - & - & - & - & - & - & - \\
\hline \begin{tabular}{|l|} 
Nitrate \\
reduction
\end{tabular} & - & - & - & - & - & - & - & - & - \\
\hline $\begin{array}{l}\mathrm{H}_{2} \mathrm{~S} \text { from } \mathrm{L}- \\
\text { cysteine }\end{array}$ & + & + & + & + & + & + & + & + & + \\
\hline \begin{tabular}{|l|} 
Pectinase \\
activity
\end{tabular} & - & - & - & - & - & - & - & - & - \\
\hline \begin{tabular}{|l} 
Phenylalanine \\
activity
\end{tabular} & - & - & - & - & - & - & - & - & - \\
\hline \multicolumn{10}{|c|}{$\begin{array}{l}\text { Tolerance to triphenyl } \\
\text { tetrazolium chloride at: }\end{array}$} \\
\hline $0.02 \%$ & & - & - & - & - & - & - & - & - \\
\hline
\end{tabular}

$+=$ positive reaction. - = negative reaction. 
Obligatory aerobic. Catalase activity was present. Acetoin production, indole formation, 2- ketogluconate formation, urease, nitrate reduction, and oxidase were all negative. Carbon sources were used oxidatively and never fermentatively. Growth occurred on D-fructose, trehalose and D-xylose but not on glycerol. Acid was formed from L-arabinose, cellobiose, D-fructose Dgalactose, D-mannose, glucose, sucrose, and trehalose but not from Dribose, L-rhamnose, salicin, sorbitol. No growth occurred at 41 but at 25, 28 and $36^{\circ} \mathrm{C}$. Esculin, casein, gelatin, potato starch and rice starch are hydrolyzed. $\mathrm{H}_{2} \mathrm{~S}$ is formed. Pectinase and Phenylalanine deaminase activity was absent. Growth was inhibited in media containing $0.02 \%$ triphenyl tetrazolium chloride. All isolates caused hypersensitivity in tobacco leaves.

Analysis of pigments.

The absorption maxima of crude pigment extracts from bacterial isolates was $443 \mathrm{~nm}$ (Fig. 3). Thin-layer chromatography showed migration of the pigments at retardation factor $\left(R_{f}\right)$ values of $0.43-0.48$ (mean 0.46 ).

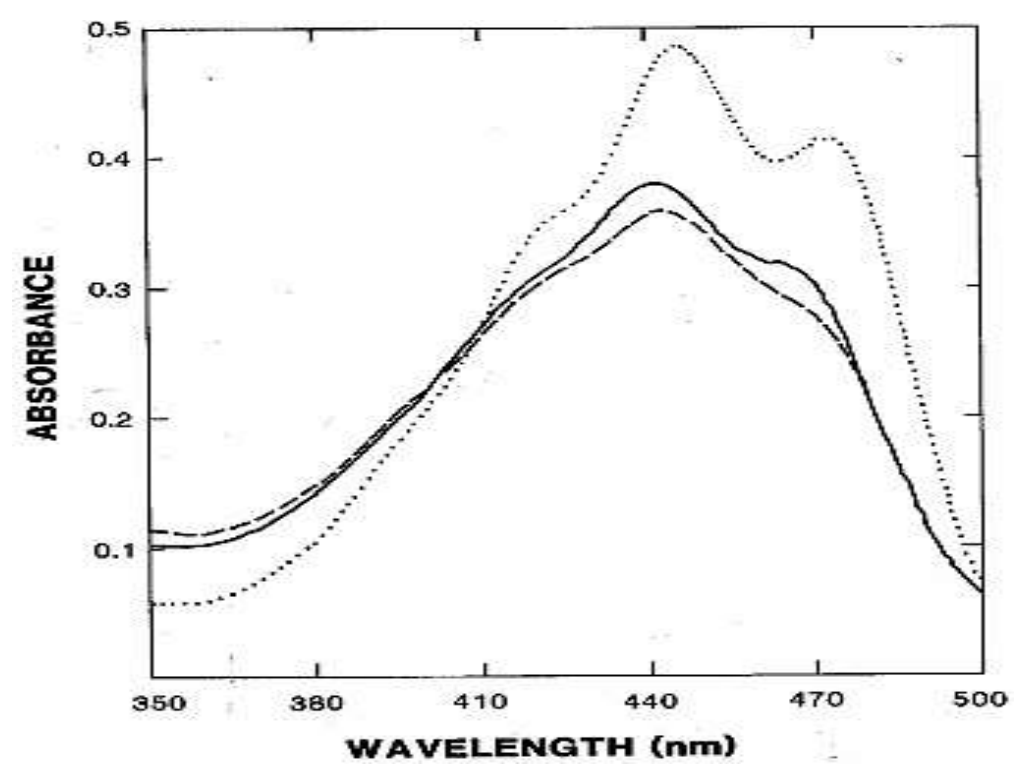

Fig. 3. Absorption spectra of crude pigment extracts from Xanthomonas oryzae pv. oryzae, isolate XOO 1 (solid line), strain of Pseudomonas paucimobilis (dotted line), and strain of Xanthomonas fragariae (dashed line).

\section{Confirmation test}

All of the selected isolates also were confirmed by Biolog system to be $X$. oryzae $p v$. oryzae. The similarity percent for all tested isolates ranged from 88 to $92 \%$ (Table 2) 
Table 3. Biolog confirmation for nine isolates of Xanthomonas oryzae pv. oryzae, isolated from symptomatic rice leaves.

\begin{tabular}{|c|c|c|}
\hline Isolate & Identity & Similarity \\
\hline 1 & Xanthomonas oryzae pv. oryzae & 88 \\
\hline 2 & Xanthomonas oryzae pv. oryzae & 91 \\
\hline 3 & Xanthomonas oryzae pv. oryzae & 90 \\
\hline 4 & Xanthomonas oryzae pv. oryzae & 92 \\
\hline 5 & Xanthomonas oryzae pv. oryzae & 92 \\
\hline 6 & Xanthomonas oryzae pv. oryzae & 89 \\
\hline 7 & Xanthomonas oryzae pv. oryzae & 92 \\
\hline 8 & Xanthomonas oryzae pv. oryzae & 91 \\
\hline 9 & Xanthomonas oryzae pv. oryzae & 88 \\
\hline
\end{tabular}

\section{Pathogenicity testing}

Typical Bacterial Blight symptoms were visible for all isolates. Symptoms on inoculated plants were characterized by chlorotic regions in leaf tissue spreading from the leaf tip toward the leaf base and forming watersoaked lesions.

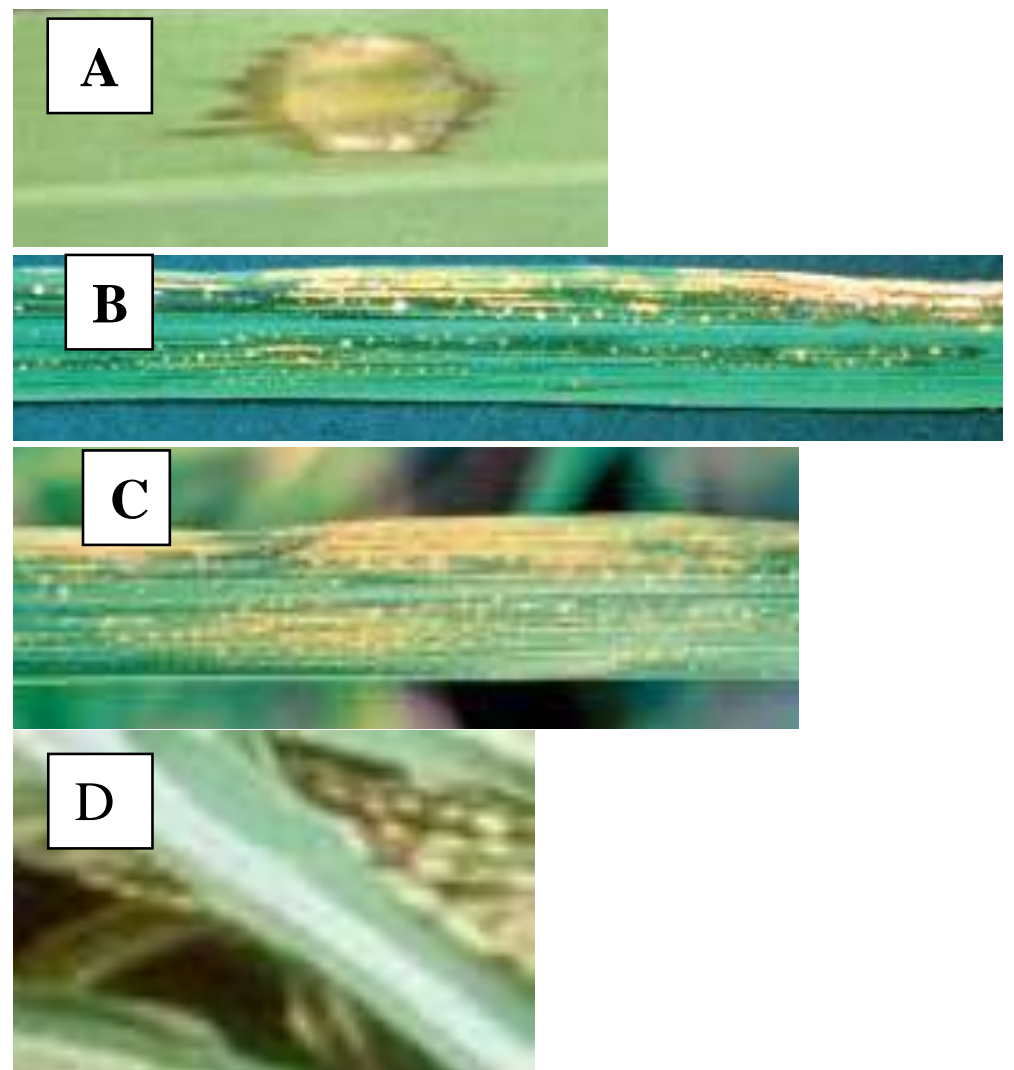

Fig. 4. Bacterial leaf blight symptoms on rice leaf resulted from artificially inoculation by isolated Xanthomonas oryzae pv. oryzae: A; initially water-soaked lesions, B; Bacterial ooze on the leaf blade, B; yellow chlorotic regions in leaf tissue and $D$; grayish-white necrotic stripes on mature leaf. 
Lesions were initially 5-10 mm wide (Fig 4; A) and varied in length from 20 to $50 \mathrm{~mm}$. Bacterial ooze, which consists of small, yellowish, spherical masses, occurred sometimes on the margins or veins of the freshly infected leaf under moist conditions (Fig. 4; B). Affected tissue did not remain water-soaked but turned chlorotic yellow (Fig. 4; C) and then necrotic (white to light tan) (Fig. 4; D). In some cases, a greyish growth of saprophytic fungi was visible on the surface of lesions after 5-7 days. Early in development, lesions exhibited wavy margins, but mature lesions were vein delimited to some extent and bounded.

\section{Virulence of isolates}

Nine isolates of $X$. oryzae pv. oryzae were evaluated for virulence by the double-needle inoculation technique on the two rice cultivars, Giza 175 and Sakha 101 (Table?). Typical Bacterial Blight symptoms (i.e., chlorotic regions in leaf tissue spreading from the leaf tip toward the leaf base and forming lesions $>15 \mathrm{~cm}$.) were visible for all isolates. There was no cultivar $x$ isolate interaction. Diversity in virulence was observed among isolates which indicated by the significant differences $(P<0.05)$ between lesion length means resulted from different isolates. According to LSD value, the isolates were divided to three groups regarding to the virulence percents. Isolates designated Xoo 1, Xoo 2 and Xoo 3 showed the highest level of aggressiveness which gives virulence percents ranged from 59 to $61 \%$ followed by Xoo 7, Xoo 5and Xoo 9 which gives virulence percents ranged from 48 to $52 \%$ whereas isolates Xoo 4, Xoo 6 and Xoo 8 showed the lowest level which gives virulence percents ranged from 29 to $36 \%$.

Table 4. Virulence of Xanthomonas oryzae pv. oryzae isolates on rice cultivars Giza 175 and Sakha 101.

\begin{tabular}{|c|c|c|c|c|c|c|c|c|c|c|}
\hline Isolate & & Xoo 1 & Xoo 2 & Xoo 3 & Xoo 4 & Xoo 5 & Xoo 6 & Xoo 7 & Xoo 8 & Xoo 9 \\
\hline & Giza 175 & 63.2 & 66.4 & 58.4 & 35.8 & 50.1 & 29.9 & 51.8 & 32.4 & 50.3 \\
\hline Virulence (\%) & $\begin{array}{l}\text { Sakha } \\
101\end{array}$ & 55.8 & 55.6 & 59.6 & 35.7 & 46.3 & 28.7 & 51.4 & 28.9 & 48.5 \\
\hline Mean & & 59.5 & 61.0 & 59.0 & 35.7 & 48.2 & 29.3 & 51.6 & 30.6 & 49.4 \\
\hline
\end{tabular}

\section{Cultivars reaction}

Among 11tested rice cultivars, no resistant cultivars were found (Table 5). All cultivars ranged from moderate susceptible to susceptible. Cultivars Giza 175, Giza 176, Giza 177, Giza 178, Sakha 101, Sakha 103, Sakha 104 and Sakha 105 were susceptible (S) which had disease score of 7 with no significant difference $(P<0.05)$ between their own total means of disease incidence. Cultivars Giza 181, Giza 182 and Sakha 102 were moderate susceptible (MS) where all gave a degree of infection equal to 5 with total means lees than $50 \%$ of disease incidence. There was no significant difference $(P<0.05)$ between cultivar $\mathrm{x}$ isolate interaction. 
Tolba, I. H. M. and R. I. El-Sharkawy

Table 5. Response of 11 Egyptian rice cultivars toward 2 isolates of Xanthomonas oryzae pv. oryzae.

\begin{tabular}{|c|c|c|c|c|c|c|c|c|c|c|c|}
\hline Cultivar & $\begin{array}{l}\text { Giza } \\
175 \\
\end{array}$ & $\begin{array}{l}\text { Giza } \\
176 \\
\end{array}$ & $\begin{array}{c}\text { Giza } \\
177 \\
\end{array}$ & $\begin{array}{c}\text { Giza } \\
178\end{array}$ & $\begin{array}{c}\text { Giza } \\
181 \\
\end{array}$ & $\begin{array}{c}\text { Giza } \\
182\end{array}$ & \begin{tabular}{|c|} 
Sakha \\
101
\end{tabular} & \begin{tabular}{|c|} 
Sakha \\
102 \\
\end{tabular} & \begin{tabular}{|c|} 
Sakha \\
103 \\
\end{tabular} & \begin{tabular}{|c|} 
Sakha \\
104 \\
\end{tabular} & \begin{tabular}{|c|} 
Sakha \\
105
\end{tabular} \\
\hline $\begin{array}{ll}\text { Mean } & \text { of } \mid \text { Xoo } \\
\text { disease } & 1\end{array}$ & 63.2 & 66.2 & 54.9 & 64.3 & 49.7 & 44.4 & 55.8 & 48.2 & 62.4 & 59.5 & 58.7 \\
\hline $\begin{array}{ll}\text { incidence } & \text { Xoo } \\
(\%) & 2\end{array}$ & 66.4 & 66.8 & 57.5 & 62.8 & 48.5 & 46.1 & 55.6 & 50.2 & 62.6 & 61.3 & 59.9 \\
\hline Total mean & 64.8 & 66.5 & 56.2 & 63.55 & 49.1 & 45.25 & 55.7 & 49.2 & 62.5 & 60.4 & 59.3 \\
\hline Score & 7 & 7 & 7 & 7 & 5 & 5 & 7 & 5 & 7 & 7 & 7 \\
\hline Response & $\mathrm{S}$ & $S$ & $\mathrm{~S}$ & $S$ & MS & MS & $S$ & MS & $\mathrm{S}$ & $\mathrm{S}$ & $\mathrm{S}$ \\
\hline
\end{tabular}

LSD between cultivars (calculated from total means of disease incidence of cultivars) =

6.135. LSD between isolates $=4.8$

\section{DISCUSSION}

Xanthomonas oryzae pv. oryzae were detected from symptomatic rice leaf samples using a procedure that combines extraction and semiselective isolation phases. The procedure was optimized for the detection of low populations of slow growing $X$. 0 . oryzae in the presence of faster growing microorganisms that are present at high populations in collected samples.

The characteristics of isolated $X$. oryzae were the same as the description of the genus phenotypic characteristics described by Vera Cruz et al. (1984), Swings et al. (1990) and David et al. (2006). Cells are straight rods, Gram negative. Motile by means of a single polar flagellum. Cells occur singly, in pairs, or sometimes in chains. Filaments may occur. Obligately aerobic. Catalase present. Indole formation, 2- ketogluconate formation, urease, egg yolk hydrolysis, nitrate reduction, and oxidase are all negative. Carbon sources are used oxidatively and never fermentatively. Starch is hydrolyzed after 7 days. Growth occurs on D-xylose, D glucose, D-fructose, D-galactose, cellobiose, sucrose, trehalose, sodium fumarate, sodium Llactate, sodium L-malate, sodium oxaloacetate, and sodium succinate, but not on L-arabinose, D-ribose, L-rhamnose, lactose, raffinose, inulin, methanol, ethanol, n-propanol, ethanediol, meso-inositol, sorbitol, dulcitol, adenine, guanine, cytosine, thymine, sodium-potassium tartrate, sodium glyoxylate, 2-keto-gluconic acid, tannic acid, p-hydroxybenzoic acid, hydroquinone, phloroglucinol, resorcinol, amygdalin, arbutin, or esculin. Acid is formed from D-glucose, D-fructose, D galactose, cellobiose, and trehalose but not from D-ribose, L-rhamnose, salicin, sorbitol, meso-inositol, dulcitol, adonitol, maltose, lactose, or inulin. Litmus milk is never acidified. No growth occurs at 4 or $35^{\circ} \mathrm{C}$ or in the presence of $3 \% \mathrm{NaCl}$. Weak growth occurs at 32 and $10^{\circ} \mathrm{C}$. Esculin, Tween 40 , and Tween 80 are hydrolyzed. H,S is formed.

Bacterial leaf blight of rice occurs at all the growth stages of rice and is manifested by either leaf blight or "kresek" symptoms. The causal organism invades plants through water pores and wounds (Mizukami 1956 and Tabei \& Mukoo 1960). Since the water pores are located at the margins of upper parts of the leaf, the lesion usually starts from the leaf margin near its tip. As the disease progresses, the tiny water soaked lesion turns yellow, enlarges in 
size progressively and develops into an elongated irregular lesion with wavy margins. Bacterial ooze, which consists of small, yellowish, spherical masses, may sometimes be seen on the margins or veins of the freshly infected leaf under moist conditions. With the passage of time, the lesion may cover on the entire blade, which turns white and later grayish owing to saprophytic growth (Tagami \& Mizukami 1962 and Ou 1985). If plant ever produces panicles, it results in sterile immature grains, which are easily broken during milling. There may be $50 \%$ reduction in yield in case of severe infection (Mew et al. 1993) whereas $10-12 \%$ yield reduction has been recorded in case of mild infection (Ou 1985). The disease is also characterized by a systemic infection phase, which is manifested by acute wilting of young plants. This is commonly referred to as the "kresek" phase (Reitsma \& Schure 1950).

Obtained isolates of Xanthomonas oryzae pv. oryzae showed significant variation in virulence on the tested rice cultivars. Temporal and spatial variations of the pathogen have been regarded as factors determining an outbreak of the disease (Mew 1987, Mew et al 1992 Goel et al. (2001)), which suggests that characterization of the pathogen variations, is a prerequisite for practical application of host resistance and other control strategies. Information on pathogen diversity can be used to identify and characterize our rice germplasm to the biotic stress. Information on the extent and distribution of pathogen variation is needed to design effective deployment strategies for varietal resistance improvement.

Evaluation of cultivars resistance is important in breeding programs Lee et al. (2003) and Li et al. (2006). Therefore, the resistance of 11 rice cultivars was characterized in this study by symptoms severity in planta using two $X$. oryzae pv. oryzae isolates collected from blighted rice in Egypt. Two weeks after inoculation, yellow lesion with wavy margin appeared on leaf margin and the leave became yellowish and dry. The data on lesion development was recorded 15 days after inoculation. X. oryzae pv. oryzae isolates gave differential response with respect to cultivars. Cultivars Giza 175, Giza 176, Giza 177, Giza 178, Sakha 101, Sakha 103, Sakha 104 and Sakha 105 were susceptible to Rice bacterial blight disease (Table 5) while cultivars Giza 181, Giza 182 and Sakha 102 showed typical disease symptoms and exhibited medium susceptibility, but no cultivar was found resistant. Host resistance is the only effective control method for the disease; therefore, breeding for resistance has been important in many countries (Mew et al. 1993, Ogawa 1993 and Ogawa et al. 1991). More than 21 BB resistance genes have been identified and characterized (Ogawa 1993 and Ogawa et al. 1991 and Lee et al. (2003)).

Breeding for bacterial blight resistance has become an essential objective of rice improvement in many countries (Mew et al. 1982). Actually, no approach is considered as an effective and economic practice to control this disease (Devadath 1989). The varietal resistance is considered as a key tool under tropical conditions. This approach is comparatively economical and more convenient to control the disease in large scale areas. In addition, knowledge of pathogen population structure, coupled with an understanding of the mechanisms that drive genetic changes in pathogen populations, is essential to formulate long-term strategies to manage the disease. 
Resistance of rice to BB has usually been evaluated quantitatively (Baw \& Mew 1988, Koch 1990 and Ogawa 1993). Recently, the resistant reaction of 12 resistance genes (Xa1 through Xa12) was classified into three infection types. Mazzola et al. (1994) reported that the resistance of IRBB21 to Filipino race 6 strain PXO99A was expressed moderately at 21 days after emergence and that the level increased with plant maturity.

\section{REFERENCES}

Anonymous. 1996. Agriculture Statistics of Pakistan (Govt. of Pakistan). Ministry of Food, Agriculture and Livestock. Food, Agriculture and livestock Division (Economic Wing) Islamabad. 13-17.

Barton-Willis, P. A., Roberts, P. D., Guo, A., and Leach, J. E. 1989. Growth dynamics of Xanthomonas campestris pv. oryzae in leaves of rice differential cultivars. Phytopathology 79:573-578.

Baw, A., and Mew, T. W. 1988. Scoring systems for evaluating varietal resistance to bacterial blight (BB): Lesion size by growth stage. Int. Rice Res. Newsl. 13(3):10-11.

Beraha, L. 1968. A rapid method for preparation of a semi-solid agar medium for detection of pectolytic enzyme activity in Erwinia carotovora. Plant Dis. Rep.52:167.

Bradbury, J.F. (1970a). Xanthomonas oryzae. CMI Descriptions of Pathogenic Fungi and Bacteria No. 239. CAB International, Wallingford, UK.

Bradbury, J.F. (1970b). Xanthomonas oryzicola. CMI Descriptions of Pathogenic Fungi and Bacteria No. 240. CAB International, Wallingford, UK.

David O. N., Pamela C. R. and Adam J. B. 2006. Xanthomonas oryzae pathovars: model pathogens of a model crop. Molecular Plant Pathology 7(5): 303-324.

Devadath, S. 1989. Chemical control of bacterial blight of rice. Pages 89-98 In: Bacterial blight of rice. International Rice Research Institute, Manila, Philippines.

Di, M., Yc, H., Schaad, N. W., and Roth, D. A. 1991. Selective recovery of Xanthomonas spp. from rice seed. Phytopathology 81:1358-1363

Dye, D. W. 1962. The inadequacy of the usual determinative tests for the identification of Xanthomonas spp. N. Z. J. Sci. 5:393-416.

Dye, D. W. 1968. A taxonomic study of the genus Erwinia. .1. The "amylovora" group. N. Z. J. Sci. 11:509-607.

Feakin, S.D. (1971) Pest control in rice. PANS Manual No. 3, pp. 69-74.

Ganamanickam, S.S., V.B. Priyadarisini, N.N. Narayanan, P. Vasudevan and S. Kavita. 1999. An overview of bacterial blight disease of rice and strategies for its management. Center for Advanced studies in Botany, University of Madras, Guindly Campus, Chennai 600 025, India. Current Science, 77(11): 1435-1444. 
Gitaitis, R. D., Sasser, M. J., Beaver, R. W., Mclnnes, T. B., and Stall, R. E. 1987. Pectolytic xanthomonads in mixed infections with Pseudomonas syringae pv. syringae, $P$. syringae pv. tomato, and Xanthomonas campestris pv. vesicatoria in tomato and pepper transplants. Phytopathology 77:611-615.

Goel, A.K., Rajagopal, L. and Sonti, R.V. (2001) Pigment and virulence deficiencies associated with mutations in the aroE gene of Xanthomonas oryzae pv. oryzae. Appl. Environ. Microbiol. 67, 245250.

Hildebrand, D. C. 1971. Pectate and pectin gels for differentiation of Pseudomonas spp. and other bacterial plant pathogens. Phytopathology 61:1430-1436.

Irey, M. S., and Stall, R. E. 1981. Value of xanthomonadins for identification of pigmented Xanthomonas campestris pathovars. Pages 85-95 in: Proc. Int. Conf. Plant Pathog. Bact., 5th, Cali, Colombia.

Jones, R. K., Barnes, L. W., Gonzalez, C. F., Leach, J. E., Alvarez, A. M., and Benedict, A. A. 1989. Identification of low-virulence strains of Xanthomonas campestris pv. oryzae from rice in the United States. Phytopathology 79:984- 990.

Kauffman, H. E., Reddy, A. P. K., Hsieh, S. P. Y., and Merca, S. D. 1973. An improved technique for evaluating resistance of rice varieties to Xanthomonas oryzae. Plant Dis. Rep. 57:537-541.

Koch, M. F. 1990. Aspects of quantitative resistance to Xanthomonas campestris pv. oryzae in rice. Ph.D. thesis. Wageningen Agricultural University, Wageningen, the Netherlands.

Kovacs, N. 1956. Identification of Pseudomonas pyocyanea by the oxidase reaction. Nature (London) 178:703.

Lee, K.S., Rasabandith, S., Angeles, E.R. and Khush, G.S. (2003) Inheritance of resistance to bacterial blight in 21 cultivars of rice. Phytopathology, 93, 147-152.

Li, Z.K., Arif, M., Zhong, D.B., Fu, B.Y., Xu, J.L., Domingo-Rey, J., Ali, J. and Vijayakumar, C.H.M., Yu, S.B. and Khush, G.S. (2006) Complex genetic networks underlying the defensive system of rice (Oryza sativa L.) to Xanthomonas oryzae pv. oryzae. Proc. Natl Acad. Sci. USA, doi: 10.1073/pnas.0507492103.

Lovrekovich, L., and Klement, Z. 1965. Triphenyltetrazolium chloride tolerance of phytopathogenic bacteria. Phytopathol. Z. 39:129-133.

Mazzola, M., Leach, J. E., Nelson, R., and White, F. F. 1994. Analysis of the interaction between Xanthomonas oryzae pv. oryzae and the rice cultivars IR24 and IRBB21. Phytopathology 84:392 397.

Mew, W.T. 1987. Study on rice bacterial blight syndrome. International research institute, P.O. Box 933, Manila, Philippines.

Mew, T. W., Alvarez, A. M., Leach, J. E., and Swings, J. 1993. Focus on bacterial blight of rice. Plant Dis. 77:5-12.

Mew, T. W., Vera Cruz, C. M., and Medalla, E. S. 1992. Changes in race frequency of Xanthomonas oryzae pv. oryzae in response to rice cultivars planted in the Philippines. Plant Dis. 76:1029-1032. 
Mew, T. W., C. M. Vera Cruz, and R. C. Reyes. 1982. Interaction of Xanthomonas campestris pv. oryzae and a resistant rice cultivar. Phytopathology 72:78\&789.

Mizukami, T. 1956. Studies on the bacterial leaf blight of rice plant on the entrance and multiplying portion of the pathogen upon the rice plant leaves (preliminary report). Agricultural Bulletin of Saga University, 4: 169-175.

Ogawa, T. 1993. Methods and strategy for monitoring race distribution and identification of resistance genes to bacterial leaf blight (Xanthomonas campestris pv. oryzae) in rice. Jpn. Agric. Res. Q. 27:71-80.

Ogawa, T., Tabien, R. E., Yamamoto, T., Busto, Jr., G. A., and Ikeda, R. 1991. Breeding of near isogenic lines for resistance to rice bacterial blight. Pages 742-743 in: Rice Genetics II. Proc. Int. Rice Genet. Symp. International Rice Research Institute, Manila, Philippines.

Ou, S. H. 1985. Rice Diseases. 2nd ed. Commonwealth Mycological Institute, Kew, Surrey, United Kingdom.

Ou, S. H. 1972. Rice diseases. Commonwealth Mycological Institute, Kew, England.

Reddy, P.R. (1984) Kresek phase of bacterial blight of rice. Oryza 21, 179187.

Reitsma, J. and P.S.J. Schure. 1950. "Kresek", a bacterial blight disease of rice. Contribution, General Agricultural Research Station, Bogor, 117: 1-17.

Schaad, N. W. 1988. A Laboratory Guide for Identification of Plant Pathogenic Bacteria. 2nd ed. The American Phytopathological Society,St. Paul, MN. 164 pp.

Tabei, H. and H. Mukoo. 1960. Anatomical studies of rice plant leaves affected with bacterial leaf blight, in particular reference to the structure of water exudation system. Bulletin National Institute of Agricultural Science, 11: 37-43.

Tagami, Y. and T. Mizukami 1962. Historical review of the researches on bacterial leaf blight of rice caused by Xanthomonas oryzae (Uyeda et Ishiyama) Dowson. Special report of the plant diseases and insect pests forecasting service No. 10. Plant protection

Division, Ministry of Agriculture and Forestry, Tokyo, Japan. 112 pp.

Vera Cruz, C. M., F. Gossele, K. Kersters, P. Segers, M. Van den Mooter, J. Swings, and J. De Ley. 1984. Differentiation between Xanthomonas campestris pv. oryzae, Xanthomonas campestris pv. oryzicola and the bacterial "brown blotch" pathogen on rice by numerical analysis of phenotypic features and protein gel electrophoregrams. J. Gen. Microbiol. 130: 2983-2999. 
Swings, J., Mooter, M. V., Vauterin, L., Hoste, B., Gillis, M., Mew, T. W., and Kersters, K. 1990. Reclassification of the causal agents of bacterial blight of rice (Xanthomonas campestris pv. oryzae) and bacterial leaf streak (Xanthomonas campestris pv. oryzicola) of rice as pathovars of Xanthomonas oryzae (ex Ishiyama 1922) sp. nov., nom. rev. Int. J. Syst. Bacteriol. 40:309-311.

Yun, M. S., Choi, Y. C., and Han, M. S. 1984. Distribution of pathogenic groups of Xanthomonas campestris pv. oryzae, bacterial leaf blight of rice, in Korea. Korean J. Plant Prot. 23:147-152.

البكتريوم Xanthomonas oryzae pv. oryzae فى مصر: تعريف وشر اسية العزلات و تفاعل الأصناف.

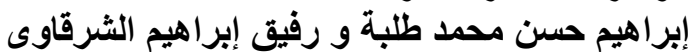

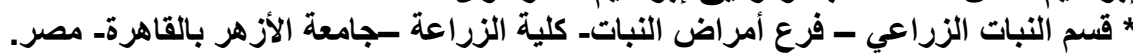

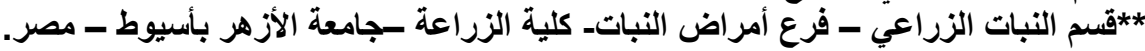

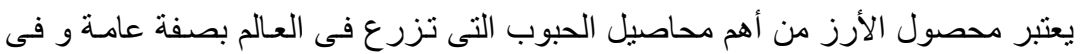

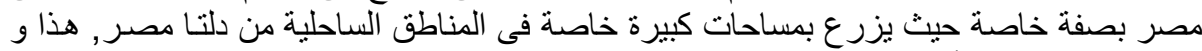

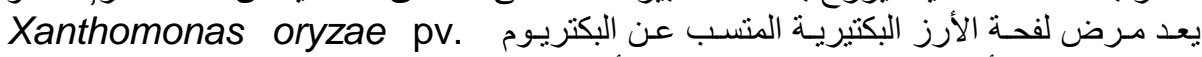

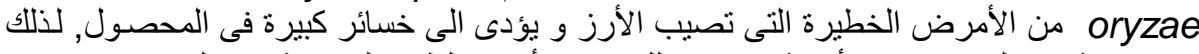

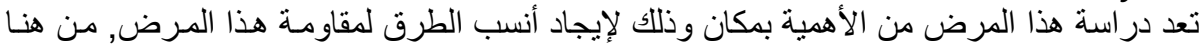

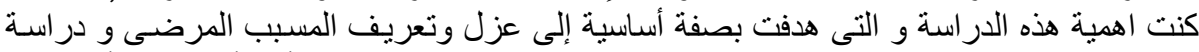

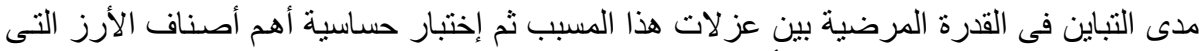
تزرع فى مصر من حيث المقاومة أو القابلية للإصابة بهذا المسبب المئب المرضى.

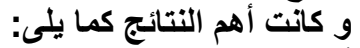
أولا عزل وتعريف المسبب المرضى:

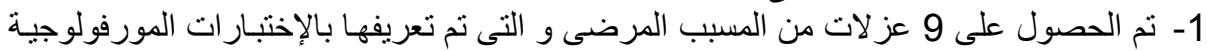

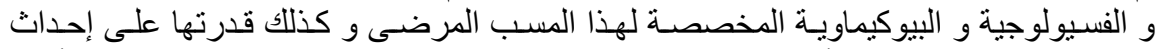

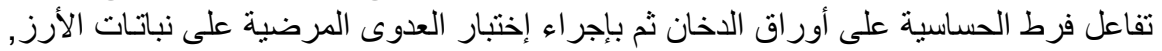

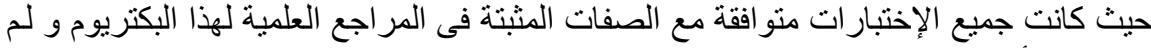

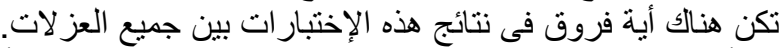

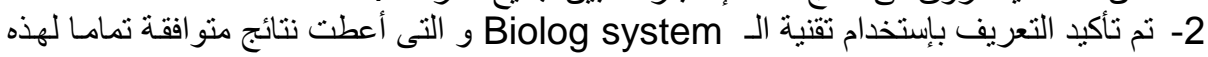

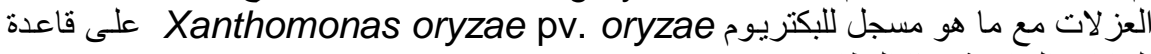

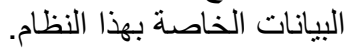
ثانيا دراسة التباين فى القدرة المرانية المرضية للعزلات: بإختبار مدى الثراسة المرضية للعزلات و الفرة ذلك على صنفى الأرز جيزة 175 و سخا 101 إتضح الأتى 1- الأى جميع العزلات أعطت أعر اض مرض اللفحة على كلا الصنفين.

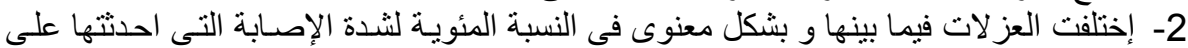

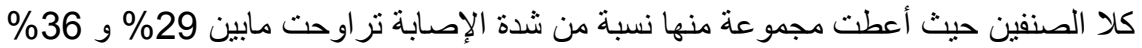

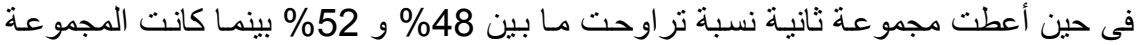
الثالثة هى الأعلى من حيث الثر اسة المرضية حيث أعطت منوسط شدة إصابة من 59\% إلى الى $\% 61$ 3- لم يكن هنالك فرق معنوى فى الثر اسة المرضية لأى من العزلات على كلا الصنفين. 


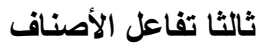

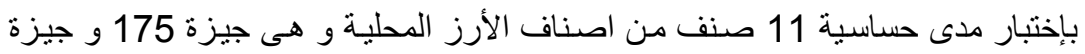

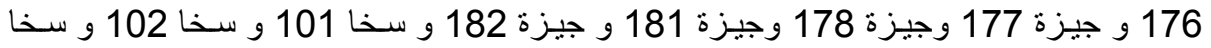

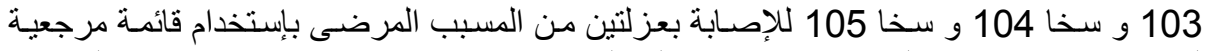

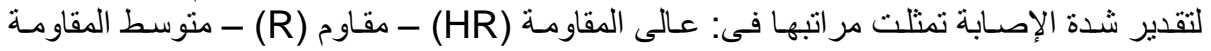

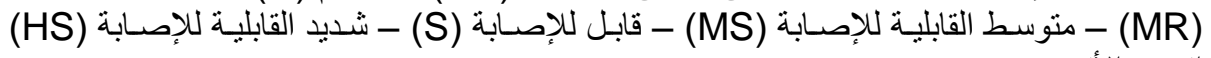

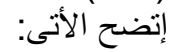

1- لـ يكن هناك صنف مقاوم من أى من الأصناف المختبرة.

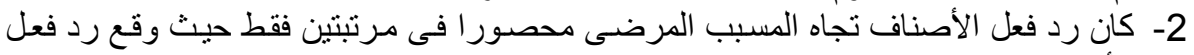

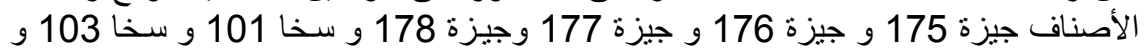

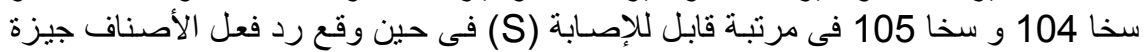

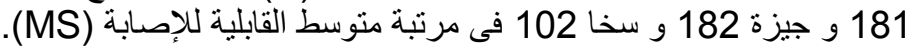

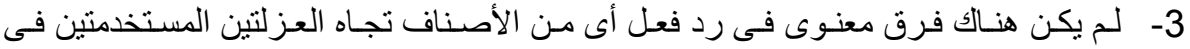
الإختبار.

كلية الزراعة - جامعة المنصورة

كلية الزراعة - جامعة الازهر

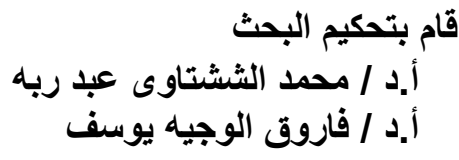

